\title{
Contributions to a theoretical framework for sustainable urban development: some conclusions of the Spanish case
}

\author{
J. L. Miralles i Garcia \\ Department of Urban Planning, \\ Polytechnic University of Valencia, Spain
}

\begin{abstract}
The period 1997-2007 was a period of economic expansion in Europe, particularly in Spain. The expansion occurred based on easy credit in a globalized economy. In Spain, a large part of the credit was allocated to civil works and construction of housing. So it caused a "housing bubble" that burst in 2007. Thus, in the period 1997-2007 unsustainable urban development was produced in Spain. Today we know a lot of the historical data of the process and its consequences in the economic recession lasting from 2007 to the present. Nowadays, it is possible to systematize the features of urban development, economic processes and behaviors of different social agents during the unsustainable development and after in Spain. Particularly in Spain, Valencia promoted especially this development model and, consequently, has become one of the paradigmatic cases. In addition, tourist residential demand has played an important role throughout this process. Tourist activity is a very important economic sector in Spain and especially on the Valencian and Mediterranean coast. This paper is a synthesis of the evolution of the main variables that explain in this case the unsustainable urban development process taking into account environmental, economic and social aspects. It also identifies the consequences. The analysis draws conclusions that can be generalized in this type of process. This allows us to generate proposals to identify the objective conditions that must be met in sustainable urban development.

Keywords: urban planning, regional planning, sustainable urban development, real estate bubble, planning legislation, property rights.
\end{abstract}




\section{Introduction}

The last real estate cycle in Spain is paradigmatic. Around 1997 began an expansive cycle of the world economy which ends in the crash of 2007. The expansive cycle in developed countries is based in bank credits for families and businesses. In Spain (see Fig. 1), the private debt of families and businesses increase from 340.026 millions of Euros in 1995 to 2.218.281 millions of Euros on the top in 2008. In 2012 the debt is 1.978.604 millions of Euros.

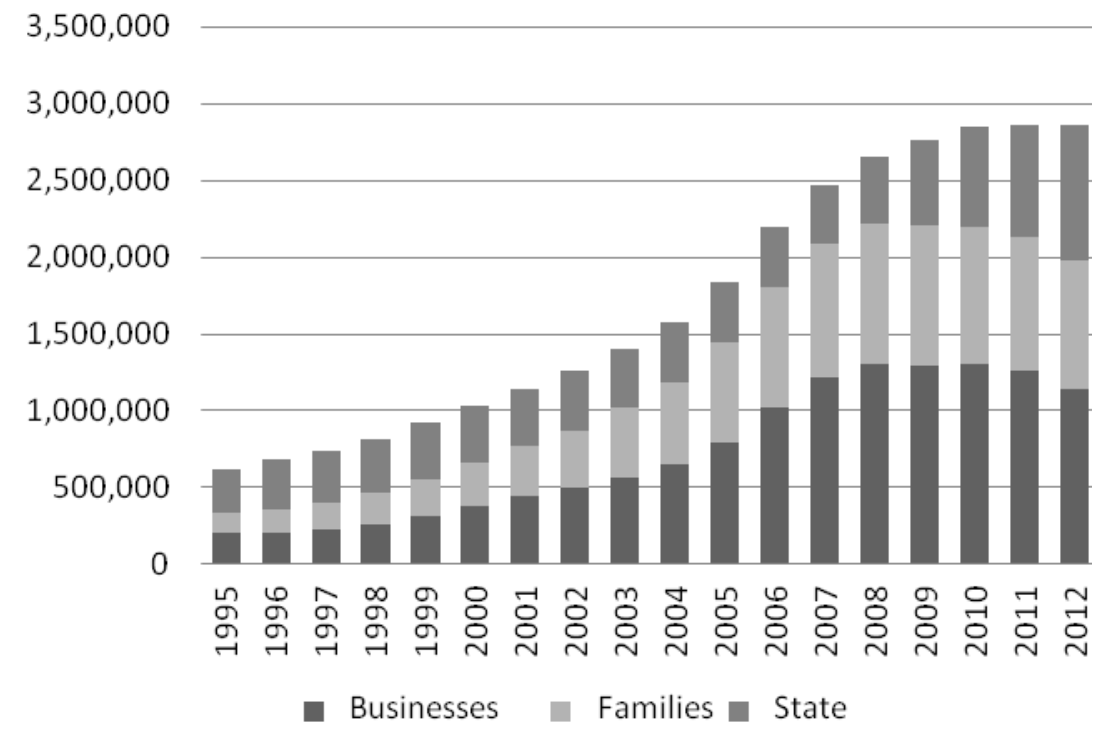

Figure 1: Spain debt in millions of Euros: businesses, families and state (origin: Bank of Spain).

An important part of this debt is due to the construction of public works or houses. Spanish saving banks and banks lent to builders and home buyers. In Spain, banks lend for $100 \%$ or more of the value of the home you are buying because the homebuyer supports the debt not only with the house but also with all its assets. Generally, construction activity is about 6\% of GDP. In Spain, during the upturn, the construction accounted for up to $11 \%$ of GDP and in Valencia's Region, arrived to $12.5 \%$ of regional GDP.

We must remember that tourism is very important in Spain and in particular, on the Mediterranean coast. So there was significant tourist urban development.

Today there are a large number of studies on different aspects and phenomena that occurred during expansive and regressive cycles of urban and economic development [1-3].

In fact, we can consider that all sustainable development process is based on three concepts:

- $\quad$ Society's Capital (monetary or natural). 
- $\quad$ Monetary interest or flows of natural goods and services.

- Consumption (monetary or natural goods and services).

A given level of Society's Capital (monetary or natural) generates a lot of interest (monetary, usually measured as GDP, or natural) that can be consumed by society. If consumption is less than the interest, for this society, its economic and social activity is sustainable. If consumption is higher than the interest, for this society, its economic and social activity is unsustainable.

In any case, every society can maintain unsustainable activity by consuming their capital. In this case, society is progressively poorer because their capital decreases and therefore also reduces the interest produced per unit of time. In practice, in the present, society is consuming the goods and services of the future.

On the other hand, society can advance their future consumption through credit. If the advance consumption is used to increase the society's capital, interest increasing can compensate for loan repayment and their costs. But if the consumption is not used to increase the society's capital, can only be returned the credit in the future by reducing the society's capital. This is the situation that has occurred in the case of Spain.

\section{Historical series of significant variables of the process of urban development in Spain and Valencia}

For Spain, the last real estate expansive cycle has been the third one. The first occurs in the period 1959-1972 and the second in the period 1985-1991. Thus the period 1994-1996 is taken as the reference period in equilibrium. In this equilibrium situation in Spain were built about 250,000 houses per year (see Fig. 2).

From 1997 begins a cycle of urban expansion based on easy access to credit for households and businesses, particularly real estate developers. In Spain, all urban development is planned. The urban plan, approved by local and regional administration, determines the urban land, the land for building by zonal plan and the land out of urban development (protected or not protected). In this period, the land for building is accepted as credit guarantee. Remember that, in this situation, the price of land for building increases each year, during the expansion phase of the bubble due to the annual increase of house selling prices.

In this period, for each year, the inhabitants of Valencia country are about 10$11 \%$ of Spain inhabitants but the houses initiated are about $11-13 \%$ of initiated houses in Spain. So the process of urban development was more intense in Valencia that Spain and also its dependence on the construction sector.

On the other hand (see Fig. 3), houses prices in 1996 are approximately the equilibrium price. Since 2000, the euro is the single currency in Europe. So Spain can't devalue its currency. At the moment, the average price of houses in Spain has decreased by about $40 \%$ in real value but has not yet reached the equilibrium value.

The speculative urban development process has resulted in tremendous growth of the housing stock. Table 1 shows the evolution of housing stock in 


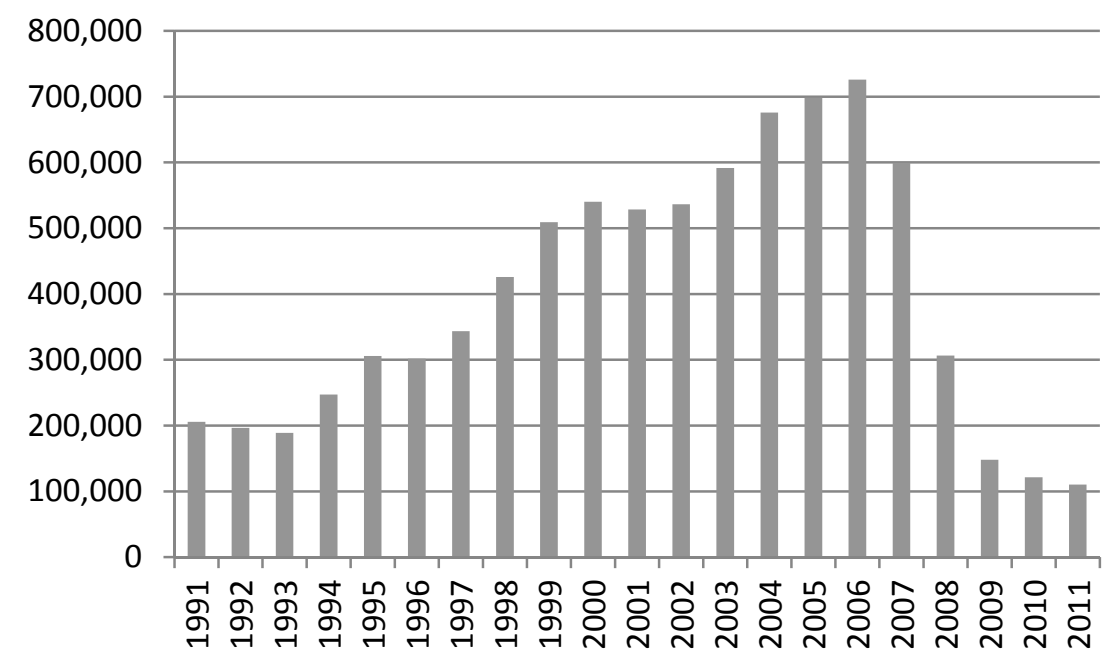

Figure 2: Housing starts each year in Spain (origin: National Statistic Institute).

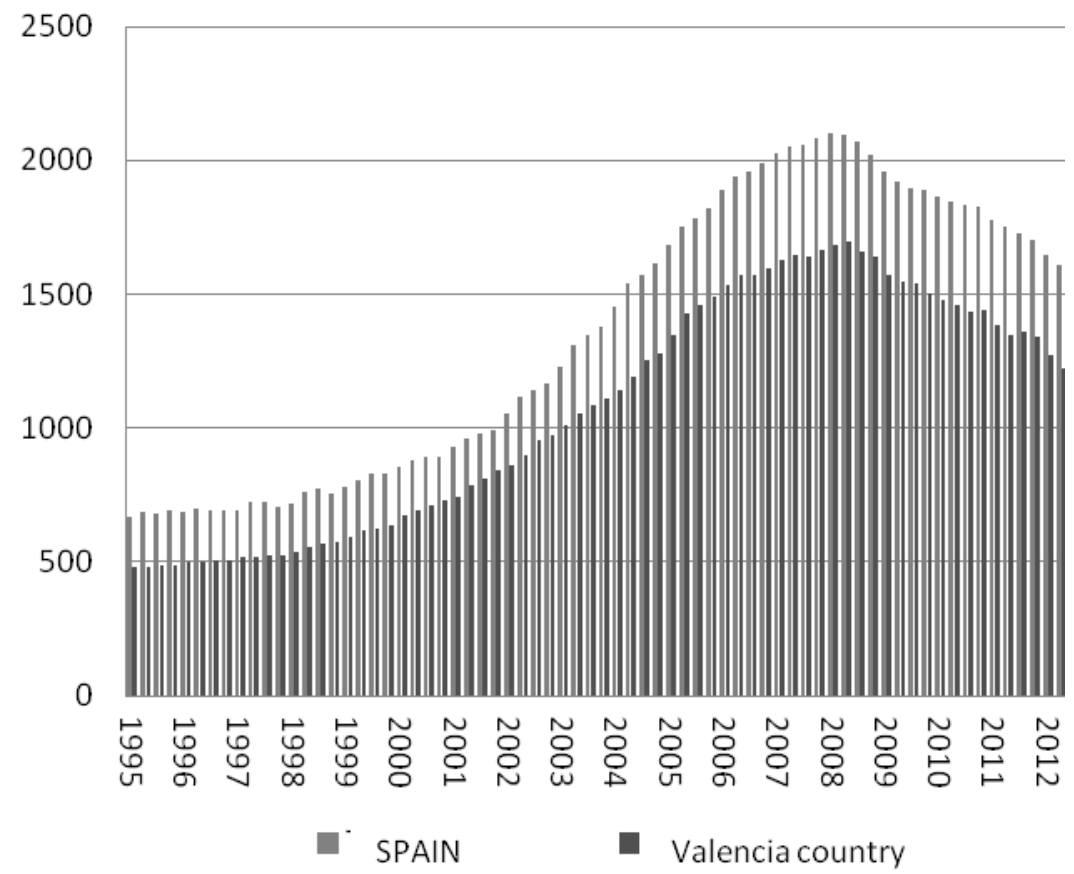

Figure 3: $\quad$ Average price houses evolution in Spain and Valencia country in $€ / \mathrm{m}^{2}$ of roof (origin: Ministry of Development,Spain). 
Spain and Valencia country. Note the high percentage of second home houses (for domestic or foreign population): around 31\% in Spain and 38-39\% in Valencia country. Most of these second homes are located in tourist areas such as the Mediterranean coast (for example Valencia).

Table 1: $\quad$ Number of houses en Spain and Valencia country, \% of houses for not principal home and houses for thousand inhabitants. Origin: Statistic National Institute (Spain) and author.

\begin{tabular}{|c|c|c|c|c|c|c|}
\hline & \multirow{2}{*}{ SPAIN } & \multirow{2}{*}{$\begin{array}{l}\% \\
\text { Houses } \\
\text { not } \\
\text { principal }\end{array}$} & \multirow{2}{*}{$\begin{array}{l}\text { Valencia } \\
\text { country }\end{array}$} & \multirow{2}{*}{$\begin{array}{l}\% \\
\text { Houses } \\
\text { not } \\
\text { principal }\end{array}$} & \multicolumn{2}{|c|}{$\begin{array}{l}\text { Houses/1000 } \\
\text { inhabitants }\end{array}$} \\
\hline & & & & & Spain & $\begin{array}{l}\text { Valencia } \\
\text { country }\end{array}$ \\
\hline 2001. & $21,033,759$ & $32.57 \%$ & $2,558,691$ & $41.66 \%$ & 511.56 & 608.83 \\
\hline 2002 & $21,551,426$ & $32.31 \%$ & $2,628,135$ & $40.70 \%$ & 515.12 & 607.42 \\
\hline 2003 & $22,059,220$ & $31.93 \%$ & $2,692,389$ & $40.42 \%$ & 516.40 & 602.20 \\
\hline 2004 & $22,623,443$ & $31.74 \%$ & $2,767,763$ & $39.34 \%$ & 523.72 & 609.20 \\
\hline 2005 & $23,210,317$ & $31.08 \%$ & $2,862,658$ & $37.91 \%$ & 526.21 & 610.06 \\
\hline 2006 & $23,859,014$ & $30.81 \%$ & $2,952,338$ & $38.14 \%$ & 533.65 & 614.19 \\
\hline 2007 & $24,495,844$ & $30.86 \%$ & $3,037,589$ & $37.87 \%$ & 541.93 & 621.82 \\
\hline 2008 & $25,129,207$ & $30.77 \%$ & $3,123,236$ & $37.65 \%$ & 544.42 & 620.97 \\
\hline 2009 & $25,557,237$ & $31.02 \%$ & $3,178,352$ & $38.07 \%$ & 546.73 & 623.86 \\
\hline 2010 & $25,837,108$ & $31.25 \%$ & $3,204,292$ & $38.29 \%$ & 549.48 & 626.85 \\
\hline 2011 & $26,018,179$ & $31.16 \%$ & $3,215,560$ & $38.08 \%$ & 551.34 & 628.38 \\
\hline
\end{tabular}

Consequently, the indicator of number of houses per thousand inhabitants is very high. When in the more developed countries of Europe, do not reach 500 homes/1000 inhabitants in Spain is greater than 500 and in Valencia country greater than 600 .

After the bursting of the housing bubble, society must pay for the purchase of this property at prices upward when its actual value is lower and there are also lower income sources. So Spanish society is poorer because must pay the debt and the same time incomes are lower.

Obviously, this large increase in activity in the construction sector has been reflected in its share in GDP. Fig. 4 shows the evolution of share construction in GDP for Spain and Valencia country.

In an equilibrium situation, around 1996, the share of construction in GDP is around 6\%. In fact, the average share of construction in GDP European countries (see Table 2) is around 6\%. Only Ireland and Iceland have had an urban development process similar to Spain (different value between SNI data and EUROSTAT data is due to homogenizing process for European data). Now if we compare the values of Spain with the values of Ireland and Iceland, in the Spanish case, the intensity of construction activity has been greater and occurred over a longer period. 
In addition, the construction sector has a strong multiplier effect on the economy. For Spain it is estimated that each job in the construction generates 1.4 jobs in other sectors of the economy.

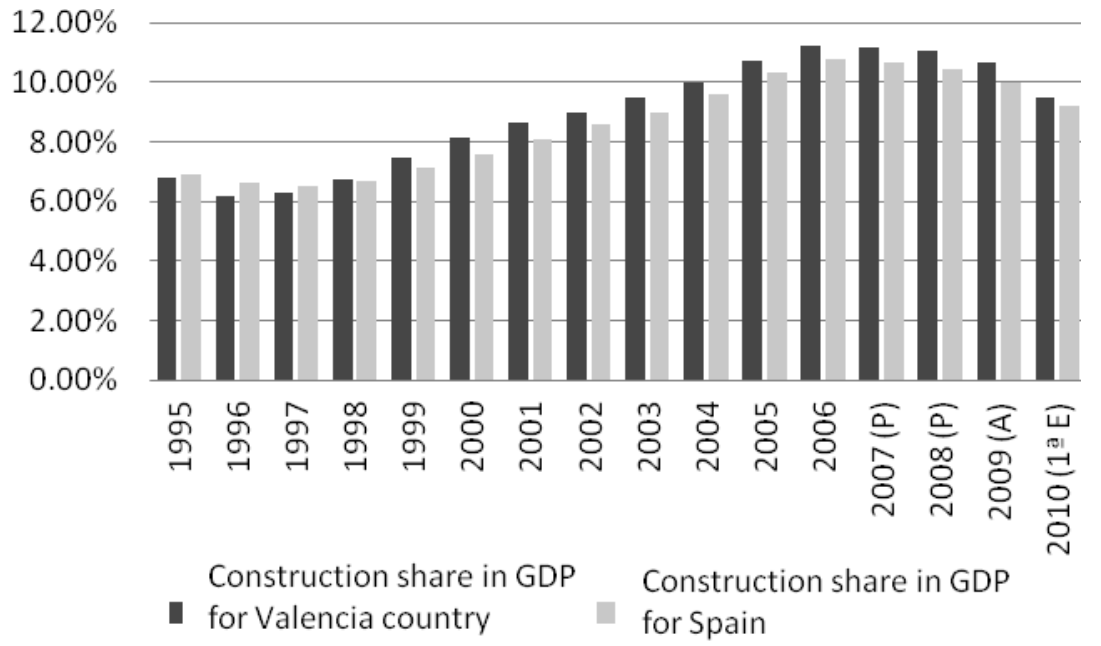

Figure 4: Construction activity, share in GDP for Spain and Valencia country (P, provisional; A, advanced; E, estimate). Origin: Statistical National Institute and author.

Table 2: $\quad$ Share of construction activity in GDP for European Union, Ireland, Spain and Iceland. Origin: EUROSTAT.

\begin{tabular}{|l|c|c|c|c|}
\hline \multicolumn{5}{|c|}{ \% GDP construction activity } \\
\hline & $\begin{array}{c}\text { EU (27 } \\
\text { countries) }\end{array}$ & Ireland & Spain & Iceland \\
\hline 2000 & 5.6 & 7.5 & 8.4 & 8.6 \\
\hline 2001 & 5.7 & 7.8 & 8.9 & 7.8 \\
\hline 2002 & 5.7 & 7.7 & 9.4 & 7.5 \\
\hline 2003 & 5.7 & 8.1 & 9.9 & 7.5 \\
\hline 2004 & 5.9 & 9 & 10.6 & 8.8 \\
\hline 2005 & 6 & 10 & 11.5 & 10.4 \\
\hline 2006 & 6.2 & 10.7 & 12.1 & 11 \\
\hline 2007 & 6.4 & 9.7 & 11.8 & 11.4 \\
\hline 2008 & 6.4 & 7.8 & 11.4 & 9.2 \\
\hline 2009 & 6.3 & 5.6 & 10.8 & 5 \\
\hline 2010 & 6 & 5.5 & 10.2 & - \\
\hline
\end{tabular}


So, if the equilibrium situation has a share construction about $6 \%$ of GDP, in general, the percentage above $6 \%$ will be unsustainable activity in the construction sector. Or a current spending based on credit, in the case of Spain, to be paid by future generations.

We can calculate the period to return to equilibrium situation in different scenarios. Under a hypothesis building 250,000 houses a year in Spain in equilibrium situation are required 10-11 years without building any new housing to return to equilibrium (14-15 in Valencia country case).

Under this hypothesis, the excess of building is between 2,390,000 to $2,770,000$ houses in Spain (380,000 to 400,000 in Valencia country) and the nominal value of excess housing is about 370,000 millions of Euros (about 50.000 millions of Euros for Valencia country). As a reference, remember what the GDP of Spain is about 1,000,000 millions of Euros.

However, the high activity of the construction sector during the boom generates a lot of jobs directly and indirectly. When the activity is paralyzed, the jobs disappear. As a result, the society must pay the debts with levels of economic activity and incomes significantly lower.
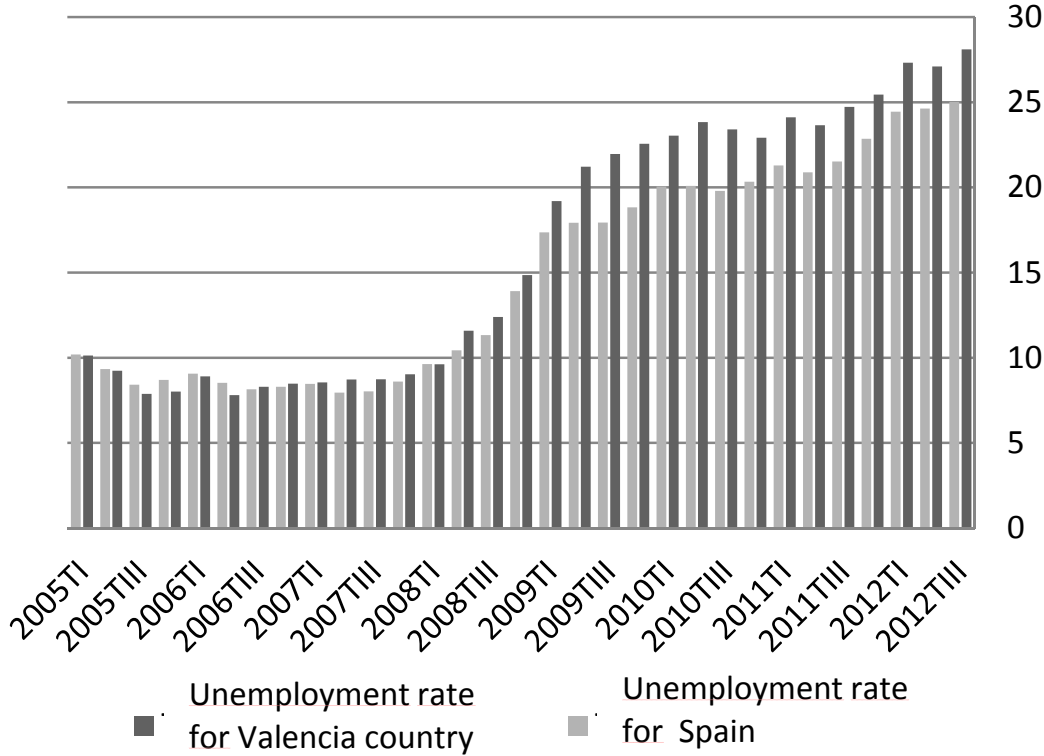

Figure 5: Quarterly unemployment rate for Spain and Valencia country according LFS (labour force survey). Origin: Statistical National Institute (Spain).

Fig. 5 shows the unemployment rates for Spain and Valencia country. So when excessive construction activity finished, job destruction has been very rapid. Unemployment rate grow very rapidly from $8 \%$ up to 20-26\%. Note that in Valencia, where the activity of the construction sector has been more intense, the loss of jobs has been greater. 


\section{Patterns and dynamics: urban, environmental, economic and social}

The unsustainable urban development process presents a set of patterns and dynamics on the following aspects:

- Urban development.

- Economic development.

- $\quad$ Impacts on the environment and landscape.

- $\quad$ General behaviors of social agents.

\subsection{Urban development}

Urban development has been generated on the expectation of continuous increase of the sales price of the houses between 1997 and 2007, but not because on real needs. An important part of the produced housings are unnecessary. However, urban development already produced is irreversible and cannot return to the initial situation. So the landscape has changed in an irreversible manner.

On the other hand, in Spain, all urban development is planned. Also it is typified the criminal punishment for illegal action against environment and planning. So the urban plans are approved by local and regional administration after, generally, a long process of elaboration and public participation. In a situation of great revenue expectation, the vast majority of stakeholders involved in the urban planning process, are in favor of the highest urban development.

In addition, the urban development process follows a logical sequence: urban planning, approval of plans, selection of public works developer, execution of urbanization works and building. So at the moment of crisis, a large number of the urban promotions reached urbanization phase but not building construction. So, after the crisis, there is a big stock of houses for sale and a big stock of plots in Spain. Many of these houses and plots stocks, today, are owned by the banks that have received as payment of debts of developers and homebuyers.

In parallel planning legislation which regulates the processes of urban development and urban planning, was modified and adapted to the stated objective of achieving a sustainable urban development. Legislation really did not modulate the effect of excessive urban development $[4,5]$.

\subsection{Economic development}

The economic consequences of unsustainable development are being terrible. Today we know that economic development that occurred during the boom period was only apparent. It really was the result of a large increase in private debts which today have to pay with interest. Moreover, to avoid the collapse of banks and saving banks, the state has given great supports converting private debt into public debt which must pay the entire society [6].

Developers and homebuyers who applied for loans and that could not afford them, have lost their homes and land. The average default rate is around $10 \%$ being much higher for promoters to homebuyers. Remember that in Spain, the 
loan guarantee is not just the house you buy but all the debtor's assets. Some homebuyers commit suicide after losing all their assets.

On the other hand, there is a decrease in the incomes of public administration (general, regional and local).

In particular, those municipalities which have large incomes as a result of the great urban development, now do not have and cannot maintain its structure. Moreover, in many cases, these local administrations are forced to maintain service networks in urbanized areas but without buildings (and therefore without population to pay taxes).

The land for building reached very high values because of the high value of the sales price of the home. The land to build market has failed as a system for optimizing the location of land uses [7]. Today, depending on the location, the value of land to build is virtually priceless because you cannot sell.

\subsection{Impacts on the environment and landscape}

The environmental impacts that have occurred during the process of urban expansion are also notable [8]. The environmental impacts translate to:

- $\quad$ Land transformation of rural areas to urban areas

- Increased consumption of natural resources (water, electric power, other energies, ...)

- Increased waste emission (sewage, solid waste, air pollution)

Urban land transformation is an irreversible impact. Usually the geographical zones interesting to protect are protected effectively. But the price of protected zones is very small (not more than 1 euro per square meter) while the price of land for building is very high (next to Valencia, up to 180 per square meter in the peak). So, usually, the owners do not want to protect their land. When real estate interests have existed to develop a protected area, the pressures to remove protection have been very strong. Sometimes legal protections are removed by modifying the urban plan to allow urban development.

On the other hand, the increased consumption of natural resources and waste emissions requires increasing urban service networks and increasing capacity of treatment plants of resources and waste.

Methodologies as ecologically balanced areas [9] help to determine the sustainability urban development in large areas.

\subsection{General behaviors of social agents}

The behaviours of social agents are very interesting in the process. In up phase or capital consumption phase, almost all social agents increase income or assets (owners, developers, homebuyers, local and regional administration, local trade, workers and local businesses, ...). So most local people are in favor of urban development. It also detects that recent experience strongly influences the actual behavior of social agents. The up period is from 1997 to 2007, around 10 years. So people perceive firsthand the daily dynamics and conclude that it is a normal situation. If any social agent, usually NGOs but not only, warns of economic collapse and proposes prudent control measures (environmental control, 
economic control, consumption control, credit regulation, ...), most people think that they are opposed to progress. In fact, in 2003, the Bank of Spain published a study [10] which concludes that a housing bubble was forming and the sales price of houses is overrated in around $30 \%$. The study generated a discussion and most of the social agents felt that the study was unrealistic because statistical trends and their analysis indicated that housing prices could still grow safely.

The up phase lasted about 10 years. In Spain the government periods are for four years. All governments in the period thought that the situation was normal and would last forever. All governments (central, regional and local) set programs for their four years in office regardless of what might happen next. When the crisis began, the central government's attitude was to deny its existence.

Even today, much of the political class and population think that the current crisis will pass and will return another growth cycle. They remember the past tense of easy money that have experienced personally. So they are waiting and wanting to repeat the growth cycle and return to speculate in land and housing.

He perceives a contradiction between the conclusions derived from direct personal experience and the conclusions derived from the analysis of global economic and financial dynamics.

The social system of values is broken. An important part of social agents does not think of producing quality goods and services to earn income and generate wealth but expect a repeat of past experience and return to enjoy easy money. Only necessity forced to do any work that is poorly paid.

\section{General scheme for sustainability in urban development}

Spanish experience allows progress in the characterization of the sustainability of the processes and identify challenges to achieve sustainable processes of urban and economic development. In Fig. 6 you can see a simply scheme of sustainability processes.

We can consider that all society lives in a territory where they have a stock of natural resources (natural capital), currency capital and assets. We will refer to it as the capital. All stock generates flows: flows of natural goods and services and flows of money.

At the same time, society consumes flows: flows of natural goods and services and flows of money.

If society consumes the same amount of flows which produces per unit of time, then the society is in equilibrium situation and his social and economic activity is sustainable.

If society consumes a larger amount of flows than the flows produces per unit of time, then the society is not in equilibrium situation and his social and economic activity is unsustainable. This situation implies that the society is consuming its capital. So capital decreases, the level of consumption is high and also the general welfare of society as well. Thereby governments want this temporary situation. 


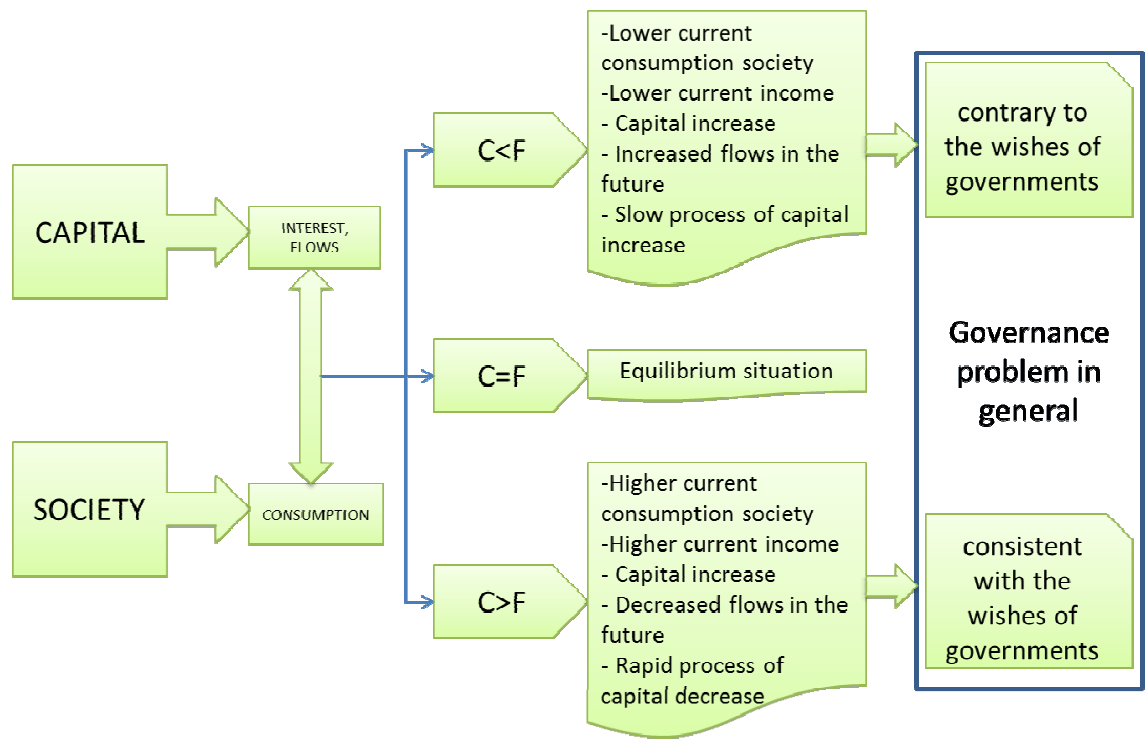

Figure 6: General scheme of sustainability processes. The problem of governance (origin: author).

If society consumes fewer flows than produced flows, we have the opposite situation. Capital grows very slowly but the benefits are generated in the longterm. Generally governments do not want this situation.

So the contradictory behavior of different social agents creates a serious problem of governance. We must consider the need to reorganize society and generate an environmental power that ensures the maintenance of consumption of flows and capital in the long term. This implies further develop appropriate sustainability indicators [11].

However, you can have a sustainable situation in $\mathrm{C}>\mathrm{F}$ case if the consumption of capital is for technology investment and new technology recovers the investment.

\section{Conclusions}

Spanish case allows detailed analysis of a paradigmatic process of unsustainable urban development and to draw general conclusions.

General conclusions are useful for managing monetary capital and natural capital.

As a global consumption of natural resources [12] are in the situation $(\mathrm{C}>\mathrm{F})$, we can say that we are seeing an "environmental bubble". The Spanish case analysis can provide guidelines for social, economic and environmental process dynamics and how to manage them. 
The analysis suggests the need to reorganize society and generate an environmental power that ensures the maintenance of consumption of flows and capital in the long term.

\section{References}

[1] Miralles i Garcia, J.L. Real estate crisis and sustainability in Spain. WIT Transactions on Ecology and the Environment, Vol. 150, WIT Press: Southampton, pp. 123-133, 2011.

[2] Gaja i Díaz, F. (coord) \& alt. Deconstruction. La desconfiguración del litoral mediterraneo español. Universitat Politècnica de València: Valencia, 2012.

[3] Miralles, J.L. \& García-Ayllón, S. The economic sustainability in urban planning: case La Manga. WIT Transactions on Ecology and the Environment, Vol. 173, WIT Press: Southampton, pp. 279-290, 2013.

[4] Miralles i Garcia, J.L., The introduction of the sustainability in the procedures regulated for urban planning: the case of the last act on urbanism, territory and landscape in the Valencian Community (Spain), WIT Transactions on Ecology and the Environment, Vol. 102, WIT Press: Southampton, pp. 505-513, 2007.

[5] Miralles i Garcia, J.L. Sustainability regulations in urban planning: the experience of the Autonomous Community of Valencia (Spain). WIT Transactions on Ecology and the Environment, Vol.120, WIT Press: Southampton, pp. 3-12, 2009.

[6] Stiglitz, J.E. The Stiglitz Report: Reforming the International Monetary and Financial Systems in the Wake of the Global Crisis. The New Press, 2010.

[7] Miralles i Garcia, J.L. The planning of peri-urban agricultural areas: the case of “L'Horta de València”. Proc. of 18th International Conference on Urban Planning, Regional Development and Information Society, eds. M. Schrenk, V.V. Popovich, P. Zeile \& P. Elisei, CORP , Roma, pp. 953-962, 2013.

[8] Miralles i Garcia, J.L., Díaz Aguirre, S. \& Altur Grau, V.J. Environmental impact on the Mediterranean Spanish coast produced by the latest process of urban development. WIT Transactions on Ecology and the Environment, Vol. 155, WIT Press: Southampton, pp. 379-389, 2012.

[9] Chen H., Ise S. \& Taniguchi M. Concept of an ecologically balanced area based on Ecological Footprint. WIT Transactions on Ecology and the Environment, Vol. 173, WIT Press: Southampton, pp. 79-86, 2013.

[10] Martínez Pagés, J. \& Ángel Maza, L. Análisis del precio de la vivienda en España. Banco de España: Madrid, 2003.

[11] Joss, S., Tomozeiu D. \& Cowlwy R. Eco-city indicators: governance challenges. WIT Transactions on Ecology and the Environment, Vol. 155, WIT Press: Southampton, pp. 109-120, 2012.

[12] Grooten M. (ed in chief), Almond R. \& McLellan R. (lead eds), Dudley N., Duncan E., Oerlemans N. \& Stolton S. (editorial team). Living Planet Report 2012. Biodiversity, biocapacity and better choices. World Wildlife Fund, Global Footprint Network \& Zoological Society of London, 2012. 